${ }^{\oplus}$ Entomologica Fennica. 29.VI.1990

\title{
Habitat distribution of carabid beetles in Tierra del Fuego, South America
}

\author{
Jari Niemelä
}

Niemelä, J. 1990: Habitat distribution of carabid beetles in Tierra del Fuego, South America. - Entomol. Fennica 1:3-16.

Carabid beetles (Coleoptera: Carabidae) were collected along the principal phytogeographic gradient, from the semiarid steppe in the northeast to the evergreen rain forests in the southwest, in Tierra del Fuego and southern Patagonia, South America. Altogether 2143 carabids belonging to 28 taxa were found. The three most abundant species were Migadops latus (30\%), Abropus carnifex (19\%) and Cascellius gravesii (14\%).

The phytogeographical gradient was divided into five habitat types, ranging from steppe and woodland to evergreen forests. The abundances of the dominant carabid species varied among the habitat types. Metius species were most numerous in the steppe and open woodland, and Trechisibus spp. and $M$. latus in Nothofagus beech forests. A. carnifex, Antarctonomus complanatus and Ceroglossus suturalis were associated with evergreen forests. C. gravesii was fairly evenly distributed among the forests, but was not found in the steppe.

A historical overview of entomological research in Tierra del Fuego is presented and the transatlantic and bipolar distribution of the Fuegian carabid fauna is discussed.

Jari Niemelä, Department of Zoology, University of Helsinki, P. Rautatiekatu 13, SF-00100 Helsinki, Finland. Present address: Department of Entomology, University of Alberta, Edmonton, Alberta, Canada T6G 2E3

\section{Introduction}

Since the first scientific expeditions to the southern parts of South America, the area has fascinated entomologists. The early entomological studies were mainly taxonomic and described the entomofauna of the region (Hope 1837, Curtis 1841, Fairmaire 1885, Champion 1918a, 1918b). This was also the case with the carabid studies. However, even later studies dealing with carabids in Tierra del Fuego mainly present lists of species found during various expeditions, with minimal information about the habitats of the collecting sites (Jeannel 1938, 1961, 1962, Schweiger 1958, Straneo 1951, 1969, Négre 1972). Accordingly, little is known about the basic ecology, and spatial and temporal distribution of most carabid species in southern South America (Peña 1966, Bonniard de Saludo 1968, Straneo 1969, O'Brien 1971, Reichart 1977, Ashworth \& Hoganson 1987) — a fact that was already recognized by entomologists in the beginning of this century (Bruch 1910-1911). Ecological and biogeographical information could open up new horizons in studies focussing on, for instance, entomofaunal connections between the southern cold temperate regions in South America, Australia, New Zealand and the intervening smaller islands.

This paper describes the distribution of carabid beetles (Coleoptera: Carabidae) in Tierra del Fuego. The occurrence of carabids was studied in different habitat types, mainly forests, along the 
principal phytogeographic gradient in the region. This gradient ranges from semiarid steppes in the northeast to extremely humid rain forests and oceanic heath in the west and south. The activity patterns of some species during a two-month sampling period in Ushuaia, Tierra del Fuego are also described.

The study is a part of a larger research project (The vegetation of Tierra del Fuego and its relation to other antiboreal and boreal regions), the aim of which is to examine the phytogeographical zonation of southern South America (Tuhkanen et al. manuscript).

\section{History of entomological research in Tierra del Fuego}

Insects have been collected in the southern parts of South America since the first scientific expeditions in the eighteenth century (Lanfranco 1977, Goodall 1979, Ashworth \& Hoganson 1987). In 1775, for instance, Johann Fabricius described two carabid species (Ceroglossus suturalis and Abropus carnifex) collected in Tierra del Fuego in 1769 by J. Banks, a botanist participating in James Cook's expedition (Fabricius 1775, Beaglehole 1962). During the nineteenth and early twentieth century, in particular, several expeditions brought back to Europe and North America collections of insects from Tierra del Fuego and Patagonia. Charles Darwin collected a good number of insects in the region during his voyage on the "Beagle" (Waterhouse 1841, 1842, Champion 1918b, Darwin 1979, Smith 1987). In addition to Darwin's collections other noteworthy expeditions to Tierra del Fuego from the entomological point of view were the King expedition in 1829-30 (Curtis 1841), the French expedition in 1882-1883 (Fairmaire 1885, 1888), the Swedish expeditions in 1895-1898, 1902-1903 and 1907-1909 (Ohlin 1896, Enderlein 1912, Schweiger 1958), and the German expedition in 1901-1903 (Enderlein 1905, 1909a).

During the twentieth century the number of expeditions with an interest in entomology has diminished. For instance, the members of the Finnish expedition to southern South America in 1928-1929 did not collect insects. However, the Danish expedition in 1978-1979 included as many as five entomologists, who collected mainly butterflies (Madsen et al. 1980). Another expedition, again with the main emphasis on butterflies, was carried out in 1981-1982 (Davis \& Nielsen 1985).

The examination of the insects collected during the early expeditions resulted in papers describing new carabid species with rough indications of the geographic distributions (e.g. Hope 1837, Curtis 1841, Waterhouse 1841, 1842, Schweiger 1958), but the detailed biogeography and ecology of the species mostly remained unexamined (Bruch 1910-1911). In spite of the various expeditions to Tierra del Fuego, the taxonomy of many insect groups, including carabids, occurring there is still poorly known (Reichart 1977). Due to taxonomic difficulties, even recent studies about insect biogeography in Fuego-Patagonia are often restricted to the level of families (e.g. Lanfranco 1977, 1981).

In addition to taxonomic entomology, the question of the transantarctic relationships of southern South American insects has received considerable attention (i.e., biological relationships of animals occurring in southern South America, Australia-Tasmania, New Zealand and the smaller islands in between). The question, first formulated for plants in the 1840s by Sir Joseph Hooker (Simpson 1940), has recently been examined by using several insect groups as examples (Gressitt \& Weber 1959, Holdgate 1961, Gressitt 1961, 1970, Brundin 1965, 1966), including carabids (Darlington 1960, 1965, Jeannel 1962). The insect faunas of the subantarctic islands are fairly well known, partly due to the low number of species (Gressitt \& Weber 1959, Gressitt 1961, 1970), but a great deal remains to be studied in southern South America before the questions about the transatlantic relationships can be answered.

The entomological research on Tierra del Fuego thus seems mainly to consist of basic taxonomic studies and inventories. Some insect groups (including carabids) have been used in delimitating biogeographical regions (Kuschel 1960, 1969, Cekalovic 1974, O'Brien 1971), but the regions are very broad covering distances of thousands of kilometres. The entomological work performed is very modest compared with the more detailed phytogeographical studies (Pisano 1977, 1980, 1981, 1982, Dollenz 1980, 1981, 1982, Roivainen 1954, Schwaar 1981). The lack of studies about 
the population and community ecology of insects, and their spatial and temporal occurrence indicates that the entomological work done in southern South America lies far behind the botanical research in that region.

\section{Material and methods}

\subsection{Study area}

The study was conducted from December 1986 through February 1987 in the southernmost part of South America, Tierra del Fuego and Patagonia (between $55^{\circ} \mathrm{S}$ and $52^{\circ} \mathrm{S}$, and between $64^{\circ} \mathrm{W}$ and $74^{\circ} \mathrm{W}$ ). Fuego-Patagonia has been divided into physiognomic phytogeographical zones (for more details see Tuhkanen 1987, Tuhkanen et al. manuscript) (Fig. 1). The precipitation increases from the semiarid steppe and woodland areas in the northeast (about $250 \mathrm{~mm} /$ year in Río Gallegos on the Patagonian steppe) through intermediate forest regions (about $570 \mathrm{~mm} /$ year in Ushuaia) to the southwestern superoceanic islands (rainfall up to $5000 \mathrm{~mm} /$ year) (Tuhkanen 1987). The annual temperature fluctuations are more pronounced in the steppe region than in the forested areas. In Río Gallegos the mean temperature of the warmest month is $12.4^{\circ} \mathrm{C}$ and that of the coldest month is $0.8^{\circ} \mathrm{C}$. In Ushuaia the corresponding temperature values are $9.2^{\circ} \mathrm{C}$ and $1.6^{\circ} \mathrm{C}$, and on the southwestern islands (Evangelistas) $8.8^{\circ} \mathrm{C}$ and $4.4^{\circ} \mathrm{C}$, respectively (Tuhkanen 1987).

The phytogeographical zones are physiognomically distinct (Fig. 1). The steppe region is dominated by grasses (mainly Festuca gracillima) and bushes (mainly Chiliotrichum diffusum). The woodlands, a mosaic of steppe and woods, are dominated by Nothofagus antarctica (one of the three southern beech species of Fuego-Patagonia) in the elevated parts. The zone forms an intermediate belt between the steppe and the closed continuous forests. As precipitation increases towards the south and west, $N$. pumilio replaces $N$. antarctica as the dominant tree species. Further to the south and west, $N$. pumilio is gradually replaced by evergreen trees requiring highly oceanic conditions. In such forests $N$. betuloides is the dominant tree. Another common evergreen tree is Drimys winteri. On the westernmost superoceanic islands, the vegetation consists of heathlands with scattered groups of Pilgerodendron uviferum, a coniferous tree, and in sheltered sites, of patches of evergreen rain forest dominated by $N$. betuloides.

The phytogeographical zonation was studied by analyzing the vegetation of 83 representative localities (area $200 \mathrm{~m}^{2}, 14 \times 14 \mathrm{~m}$ ) along seven transects (I to VII) through the zones. The vegetation of these localities will be described in detail elsewhere (Tuhkanen et al. manuscript).

\subsection{Habitat types along the phytogeographical gradient}

The localities were classified into five habitat types according to their vegetation, and the carabid samples were pooled within each type. Phytogeographically the habitat types follow the gradient of increasing precipitation, from dry steppe and woodland in the northeast to the evergreen rain forests in the southwest. The localities were classified with the help of a botanist on the expedition, Mr. Ilpo Kuokka. The vegetation of the habitat types is described in Table 1. The localities included in each of the habitat types are given in Appendix 1. The habitat types are the following:

1) Steppe (dominated by C. diffusum) and woodlands, forest patches in the steppe (dominated by $N$. antarctica), occur in the northern parts of the main island. In the steppe a mosaic of $F$. gracillima bunch grassland and tall shrubs (mainly $C$. diffusum and to some extent $\mathrm{Ber}$ beris buxifolia) prevails.

Woodlands of $N$. antarctica appear towards the southeast. The canopy cover is lower and the cover of the shrubs is higher than in the other habitat types. The characteristic plant species in the field layer include two species of rhizomatous ground ferns (Blechnum penna marina and Asplenium dareoides) and Taraxacum officinale. The moss cover is poor. The organic content of the topsoil is high, but very little loose litter or peat is found. Two localities (II/4 and II/5) with open, dry and degraded woodlands dominated by scattered sub-canopy trees, $D$. winteri and Maytenus magellanica, were included in this type. 


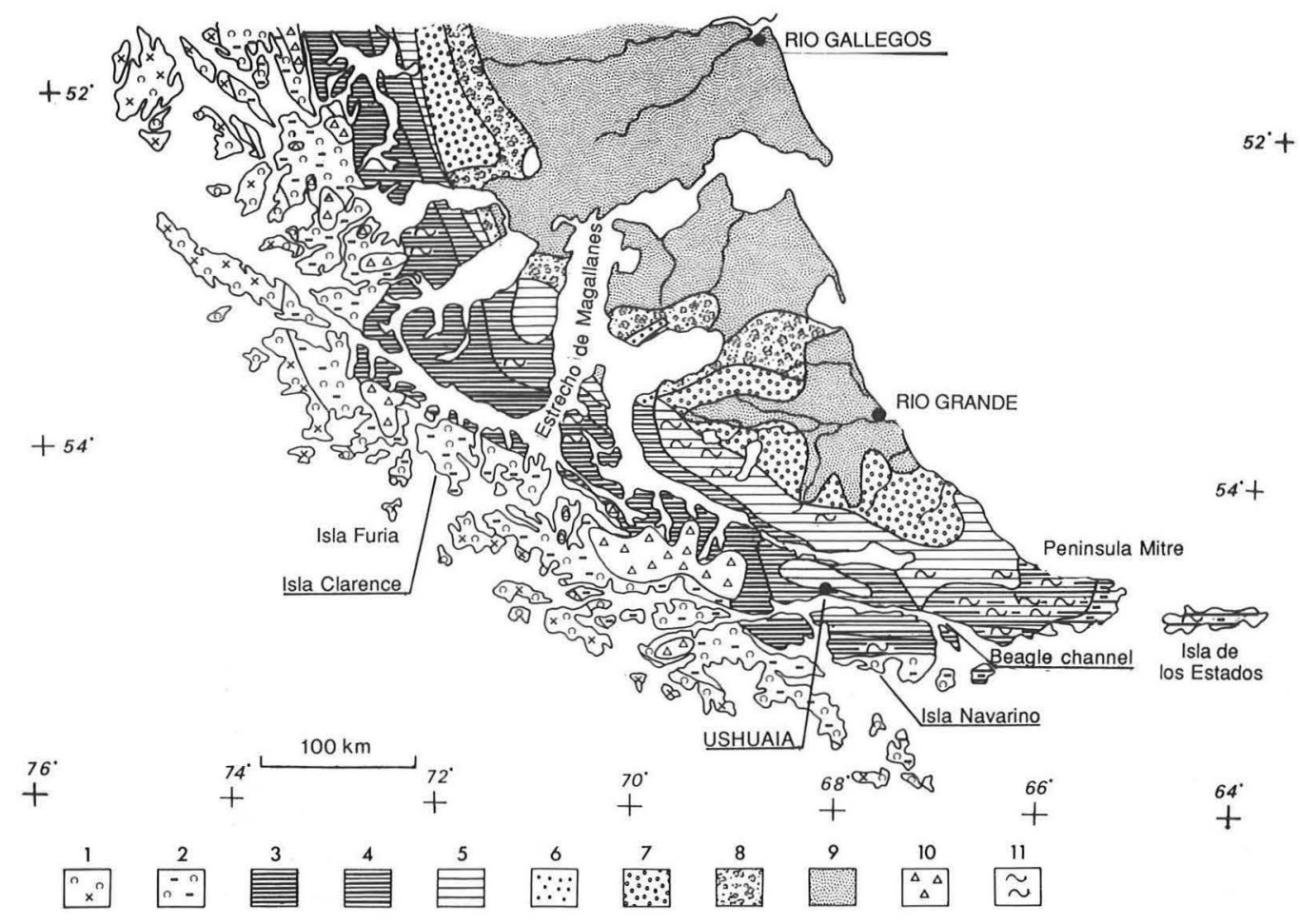

Fig. 1. The main phytogeographical zones in Tierra del Fuego and Patagonia. The Andes divide the area into two distinct phytogeographic zones: semiarid steppe in the northeast, and evergreen rain forest and oceanic bogs in the southwest. Between these two zones there is a belt of moderately humid Nothofagus-dominated forests. The numbers in brackets refer to the habitat classification used in the present paper (see text). The geographical names used in the text are given (Evangelistas is located in zone 1 slightly outside the map to the north). - Symbols: 1. Predominantly exposed igneous rocks without vegetation on the outermost Pacific islands. Scrub forest (Nothofagus betuloides - Drimys winteri) mixed with dense shrubbery in sheltered locations. - 2. Blanket bogs (Astelia pumila and Schoenus antarcticus) with scattered Pilgerodendron uviferum stands of the outer Pacific archipelago. Forests of type 3 in sheltered sites and scrub of type 1 on exposed hillsides. Localities I/04-I/ 11 and $O$ belong to this type. - 3. Dense dark evergreen forests $(N$. betuloides $-D$. winteri) of the inner Pacific archipelago with a continuous cover of Hymenophyllum spp. and Hepaticae. Blanket bogs of type 2 frequent on level land (5). - 4. Mixed evergreen (N. betuloides - D. winteri) and deciduous (N. pumilio-N. antarctica) forests, often multistoreyed tall shrubbery. Field layer predominantly herbaceous, ground layer of leaf mosses (4). - 5 . Deciduous forest of $N$. pumilio with poor undergrowth (owing to guanaco grazing), the evergreen component almost absent (2, habitat 3 has richer undergrowth). - 6. Evergreen woodland of round-topped $D$. winteri, Maytenus magellanica and Embothrium coccineum. Originally with a sparse herbaceous undergrowth, but sometimes invaded by the shrubbery of type 8 (the two localities of this type, II/04 and II/05, are included in habitat 1 in the present study). -7 . Woodland or forest islands of deciduous beeches ( $N$. antarctica, $N$. pumilio) with predominantly grass undergrowth. Lowlands often form climatic steppes or slowly drained grass fens (1). - 8 . Chiliotrichum diffusum-dominated shrub steppe rich in dwarf shrubs and both forest and steppe herbs. Grasssedge fens occur in the lowlands (1). - 9. Magellanic bunch grass steppe (Festuca gracillima) with many small steppe herbs and semiwoody dwarf shrubs. Valley lowlands often dominated by grass fens, (1). - 10. Glacier. - 11. Raised or hanging bogs (Sphagnum magellanicum) common. 
2) Interior beech forests dominated by $N$.pumilio occur in the central and northern parts of the main island. The field layer vegetation is sparse and undiversified, and lacks characteristic plant species. There is abundant leaf litter on the ground.

Table 1. The percentage cover of the abundant and characteristic plant species in the habitat types. S\&W = steppe and woodland, IBF = interior beech forest, $\mathrm{CBF}=$ coastal beech forest, $\mathrm{MBF}=$ mixed beech forest, EGF = evergreen forest.

S\&W IBF CBF MBF EGF

\begin{tabular}{lrrrrr}
\hline Canopy and understory & & & & & \\
Drimys winteri & 3 & 0 & 0 & 7 & 17 \\
Nothofagus antarctica & 14 & 0 & 3 & 10 & 1 \\
N. betuloides & 0 & 0 & 1 & 41 & 74 \\
N. pumilio & 8 & 81 & 75 & 42 & 12 \\
Canopy \& underst. total & 25 & 81 & 79 & 100 & 104
\end{tabular}

Shrubs

Berberis buxifolia

B. ilicifolia

Chiliotrichum diffusum

Pernettya mucronata

Shrubs total

$\begin{array}{rllll}13 & 0 & 0 & 0 & 0 \\ 0 & 2 & 1 & 4 & 3 \\ 27 & 0 & 0 & 0 & 0 \\ 9 & 0 & 0 & 0 & 0 \\ 49 & 2 & 1 & 4 & 3\end{array}$

Field layer

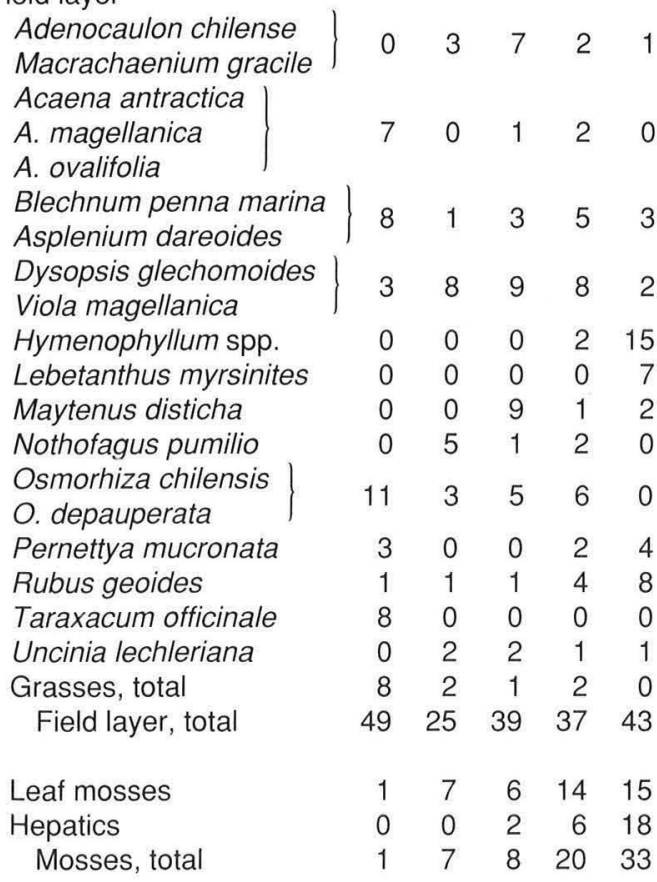

3) Coastal beech forests of N.pumilio are located in the southern, coastal parts of the main island or to the south of it (Isla Navarino). The undergrowth is slightly richer than in the previous type, indicating higher humidity of the forests. The typical plant species in the field layer include Adenocaulon chilense and Macrachaenium gracile, soft-ground herbs strongly associated with dry leaf litter and shady beech forests, and Maytenus disticha. The moss cover is somewhat thicker and the layer of leaf litter is thinner than in the previous type.

4) Mixed beech forests, dominated by the deciduous $N$. pumilio and the evergreen $N$. betuloides, are located on the coastal mountains or in Peninsula Mitre. The forests have a twin canopy. A typical species of the shrub layer is B. ilicifolia. The field layer vegetation is more diverse than in the previous type and is characterized by Hymenophyllum spp., rhizomatous ground ferns requiring wet soil, $B$. penna marina, A. dareoides and Rubus geoides. The moss cover is clearly thicker than in coastal beech forests. The humus layer is distinct but not thick.

5) Evergreen forests are found in highly oceanic and humid conditions. They are dominated by $N$. betuloides and to a lesser degree by another evergreen tree, $D$. winteri. Other evergreen tree species found are Embothrium coccineum and Maytenus magellanica. There are many shrubs, the most abundant being $B$. ilicifolia . The field layer vegetation is characterized by Hymenophyllum spp.,Lebetanthus myrsinites, Pernettya mucronata and $R$. geoides. Osmorhiza spp., typically found in drier and more open beech forests, are absent. The ground is covered extensively by mosses. Generally a fairly thick humus layer, soaked with water, is found.

The nine localities on the superoceanic islands were excluded from the classification, as only five carabids were found there (Appendix 1). Localities IV/9 (open, rocky mountain slope) and V/4 (degenerating forest) were excluded as well, as they did not fit properly into any type. Accordingly, the number of localities divided among the types was 62 .

In addition to the above mentioned localities with vegetational data, I did some collecting in a 
number of localities in which no vegetation studies were made (Appendix 1). These localities were not included in the above classification, but their samples are used as additional information on the distribution of carabids in different habitats.

\subsection{Sampling methods and identification of the carabids}

Carabids were sampled in 78 (found in 68 localities) of the 83 localities along the transects. The main sampling method used was manual collecting. The beetles were sought under bark on dead trees, under fallen trees and branches, under stones, etc. The collecting time was 30-45 minutes/locality. In spite of the rather long collecting period (15 December to 14 February), the samples from different habitat types are comparable, as the localities were studied in random order, i.e. samples from localities representing each phytogeographical zone were taken during the whole study period.

In the majority of the localities, samples were also taken from the litter by sieving an area of $1 \mathrm{~m}^{2}$ with a metallic net with a $8-\mathrm{mm}$ mesh.

The activity patterns of the species during the growing season were studied with pitfall traps (plastic cups, diameter $65 \mathrm{~mm}$ and volume 170 $\mathrm{ml})$. The traps were partially filled with water and detergent, and placed in two lines (2-3 $\mathrm{m}$ apart). Thirty-two traps were in operation continuously from December 14, 1986 through February 20, 1987. The dates of collecting the samples are given in Table 4. The locality was a hill slope (Montes Martial) in the outskirts of Ushuaia, facing the Beagle channel. It represents the mixed beech forest type described above with $N$. betuloides $(50 \%)$ and $N$. pumilio $(40 \%)$ as the dominant trees. The age of the trees was $30-40$ years, mean height $14 \mathrm{~m}$, and canopy cover $85 \%$. The field layer vegetation was rather poor, the most abundant species being Adenocaulon chilense (coverage $0.5 \%)$, Osmorhitza chilensis $(<0.5 \%)$, Uncinia lechleriana $(<0.5 \%)$ and Cardamine glacialis $(<0.5 \%)$. The ground was mostly covered by litter $(95 \%)$. There were many fallen trees in the locality.

A methodological comparison between manual collecting and pitfall trapping (a set of 15 traps in operation for 10 days) was conducted in two additional sites (IV/4, IV/5).

I used several keys to identify the carabids (e.g. Ruiz Pereira 1936, Jeannel 1938, 1962, Straneo 1951, 1979, Balazuc 1957, Bonniard de Saludo 1968, Uéno 1971, Mateu \& Négre 1972, Johns 1974, Reichart 1977). The collections of the British Museum (Natural History) were also used as references. Help with the identification of the species was kindly provided by Prof. Allan C. Ashworth (Geology Department, University of North Dakota, USA) and Mr. Sergio Roig (Universidad Nacional de La Plata, Argentina).

\section{Results}

As was to be expected, the identification of the specimens was difficult, and a part of them could only be identified to genus (Table 2, Table 3 and Appendix 1). I have given a species name only if the identification has been unambiguous. Thus, there are several Metius and Trechisibus species without a complete name. However, I can give some suggestions regarding the identity of the Trechisibus species: Trechisibus sp. 1 is probably T. pernitidus Jeannel (det. S. Roig). Trechisibus sp. 2 resembles very closely $T$. antarcticus Dejean (det. JN and S. Roig). Trechisibus sp. 3 belongs to the nigripennis group and resembles T. australis Jeannel or $T$. germaini Jeannel (det. S. Roig).

The total carabid sample consists of 2143 specimens belonging to 28 taxa. The most abundant species were Migadops latus (30\% of the total sample), Abropus carnifex (19\%), and Cascellius gravesii $(14 \%)$. The sieve samples were small, but the same species were found by sieving as by hand collecting (Appendix 1). The samples from each locality are given in Appendix 1.

\subsection{The distribution of carabids along the phytogeographical gradient}

Altogether 1456 individuals of 22 taxa were collected in the five habitat types along the phytogeographical gradient (Table 2). The most abundant species was $M$. latus $(31 \%)$, followed by $A$. carnifex $(26 \%)$ and $C$. gravesii $(15 \%)$. On the average, 23 individuals were found per locality, but 
the variation was considerable (from 1 to 103 individuals/locality). The sample sizes were relatively similar in interior, coastal and mixed beech forest, and in evergreen forest (mean 20-30 individuals/locality), but in the steppe and woodland type, the sample sizes were considerably lower (11 ind./locality). In the nine localities on the westernmost superoceanic islands (Isla Clarence and Isla Furia), only five individuals of three species were found.

Most of the nine abundant carabid species ( $>2 \%$ of the pooled sample) were associated with certain habitat types. Two Metius species (M.

Table 2. The numbers of carabids sampled (manual collecting) in the five habitat types. The nine most abundant species are given first. - S\&W = steppe and woodland, IBF = interior beech forest, CBF = coastal beech forest, $\mathrm{MBF}=$ mixed beech forest, $\mathrm{EGF}=$ evergreen forest.

S\&W IBF CBF MBF EGF Total

\begin{tabular}{|c|c|c|c|c|c|c|}
\hline Metius bradyt & 46 & 0 & 0 & 0 & 1 & 4 \\
\hline M. blandus & 23 & 2 & 8 & 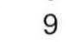 & & \\
\hline Trechisibus sp. 2. & 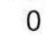 & 44 & 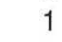 & 0 & 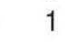 & \\
\hline \multicolumn{7}{|l|}{ Nothotrechisibus } \\
\hline horr & 0 & 0 & 141 & 0 & 0 & 14 \\
\hline Migado & 6 & 113 & 187 & 65 & 85 & 45 \\
\hline Cas & 0 & 43 & 55 & 76 & 45 & 21 \\
\hline Ceroglo & 0 & 1 & 8 & 7 & 13 & \\
\hline Abropus carnifex & 0 & 0 & 26 & 153 & 194 & 37 \\
\hline \multicolumn{7}{|l|}{ Antarctonomus } \\
\hline complanatus & 0 & 0 & 6 & 16 & 30 & 5 \\
\hline
\end{tabular}

Aemalodera

centromaculata $\quad \begin{array}{lllllll}0 & 0 & 1 & 2 & 1 & 4\end{array}$

A. testacea

Cascellius aeneoniger 0

C. hyadesi 0

Metius sp. 2.

Metius sp. 3.

Metius sp. 4.

Metius sp. 5.

Metius sp. 7.

Plagiotelum irinum

Pycnochila fallaciosa

Trechisibus sp. 1

Trechisibus sp. 3.

Total

Number of species

Number of localities $\begin{array}{llllll}89 & 204 & 447 & 340 & 376 & 1456\end{array}$

$\begin{array}{llllll}8 & 6 & 12 & 12 & 10 & 22\end{array}$

$\begin{array}{llllll}8 & 8 & 15 & 17 & 14 & 62\end{array}$

blandus and $M$. bradytoides) were most abundant in the steppe and woodland type (Table 2 and Fig. 2). Trechisibus sp. 2 and Nothotrechisibus hornensis were almost entirely found in interior and coastal beech forest, respectively. Moreover, these species were very local: $N$. hornensis, represented by 141 individuals, and Trechisibus sp. 2, represented by 47 , were each collected from only four localities, but never from the same one (see Appendix 1). M. latus was a habitat generalist, being found in all habitat types, but most abundantly in interior and coastal beech forest. $C$. gravesii was fairly evenly distributed among the closed forests (from interior beech forest to evergreen forest), but it was absent from steppe and woodland. Ceroglossus suturalis, Abropus carnifex and Antarctonomus complanatus were found only in the humid forest types (from coastal beech forest to evergreen forest). It may be noted that practi-

Table 3. The numbers of carabids collected in the additional localities described in Appendix 1 divided into four habitat types. The distribution of the localities among the types is as follows: grassland $A, B, D, H, I$, $\mathrm{K}, \mathrm{M}, \mathrm{N}$; dry sand/gravel sites without vegetation $\mathrm{C}, \mathrm{G}$, IV/09; beech forest E, J, L; blanket bog F. Species mentioned in the text are listed first. - GS = grassland, $\mathrm{SG}=$ sand/gravel, $\mathrm{BF}=$ beech forest, $\mathrm{BB}=$ blanket bog.

GS SG BF BB Total

\section{Metius blandus}

M. bradytoides

Metius sp. 2.

Metius sp. 3.

Metius sp. 5.

Trechisibus sp. 2.

Trechisibus sp. 3.

Barypus clivinoides

Oopterus soledadinus

Bembidiomorphum

convexum

Aemalodera centromaculata

Antarctonomus complanatus

Bembidini sp. 1.

Cascellius gravesii

Ceroglossus suturalis

Harpalini sp.

Migadops latus

Trirammatus sp.

$\begin{array}{rrrrr}15 & 3 & 0 & 0 & 18 \\ 10 & 0 & 1 & 0 & 11 \\ 1 & 0 & 0 & 0 & 1 \\ 3 & 0 & 4 & 0 & 7 \\ 16 & 0 & 1 & 0 & 17 \\ 52 & 0 & 6 & 0 & 58 \\ 7 & 23 & 0 & 0 & 30 \\ 9 & 0 & 0 & 0 & 9 \\ 10 & 6 & 0 & 0 & 16 \\ & & & & \\ 0 & 0 & 0 & 5 & 5 \\ & & & & \\ 0 & 0 & 1 & 0 & 1 \\ 1 & 0 & 0 & 0 & 1 \\ 3 & 0 & 0 & 0 & 3 \\ 1 & 0 & 0 & 0 & 1 \\ 0 & 0 & 3 & 0 & 3 \\ 1 & 0 & 0 & 0 & 1 \\ 5 & 1 & 0 & 0 & 6 \\ 1 & 0 & 0 & 0 & 1\end{array}$



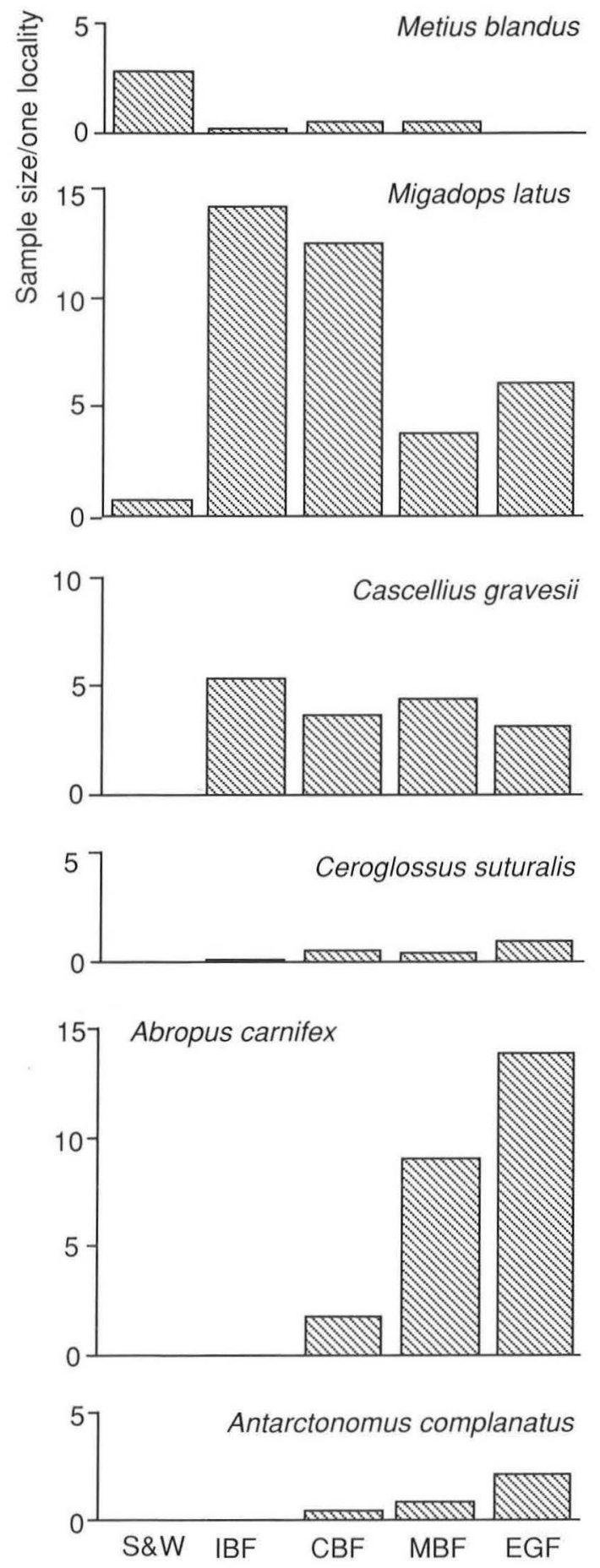

Fig. 2. Sample sizes of six abundant species in the habitat types. cally all specimens of $A$. complanatus were collected in the easternmost part of Peninsula Mitre (see Fig. 1), along transects VI and VII (Appendix 1).

The sample sizes of the remaining species were quite low, but some general observations can be made. The Metius species occurred mostly in steppe and woodland, and Cascellius aeneoniger and $C$. hyadesi occurred in the humid forests (from coastal beech forest to evergreen forest) (Table 2). In fact, of the five carabids found on the superoceanic islands two were $C$. hyadesi and one was $C$. aeneoniger (Appendix 1).

The occurrence of the species in the additional localities confirms the above observations: Metius and Trechisibus species occur in open, dry habitats, such as grasslands, meadows, and sand-gravel sites without vegetation (Table 3 ). Three new species were found in the additional collecting localities. Barypus clivinoides and Oopterus soledadinus occurred in dry and open habitats, whereas Bembidiomorphum convexum was found running on a blanket bog on Isla Navarino (Appendix 1).

Carabids were often found in aggregations under logs, branches etc. In localities $\mathrm{VI} / 5$ and $\mathrm{VII} / 1$, for instance, 10-15 specimens of $A$. carnifex were found within an area of about $100 \mathrm{~cm}^{2}$ under bark of a fallen tree.

\subsection{Seasonal occurrence and methodological comparison}

The two-month pitfall trapping in the outskirts of Ushuaia yielded 327 individuals of six species (Table 4). The most abundant species was $M$. latus ( $41 \%$ of the sample) followed by A. complanatus $(28 \%)$ and C. gravesii (17\%). All the species were more abundant in the beginning of the period (December) than later in the season (Table 4).

To compare the results of pitfall trapping and manual collecting, I sampled carabids by both methods in three localities (IV/4, IV/5 and Ushuaia pitfall locality). The samples obtained by the two methods were fairly similar in locality IV/4 (Table 5). In Ushuaia manual collecting yielded no $A$. complanatus. In locality IV/5 no C. suturalis was obtained by manual collecting. 
Table 4. Carabids collected with pitfall traps in Ushuaia in six sampling periods between December 14, 1986 and February 20, 1987. The dates of emptying the traps are given.

\begin{tabular}{lrrrrrrr}
\hline & \multicolumn{1}{c}{ Dec. } & \multicolumn{3}{c}{ January } & \multicolumn{4}{c}{ February } \\
& 23 & 1 & 12 & 26 & 11 & 20 & Total \\
\hline Abropus carnifex & 14 & 6 & 0 & 2 & 1 & 0 & 23 \\
Antarctonomus complanatus & 31 & 14 & 11 & 11 & 21 & 3 & 91 \\
Cascellius gravesii & 9 & 10 & 13 & 7 & 11 & 5 & 55 \\
Ceroglossus suturalis & 7 & 5 & 3 & 2 & 2 & 3 & 23 \\
Migadops latus & 32 & 38 & 2 & 28 & 21 & 14 & 135 \\
Oopterus soledadinus & 0 & 0 & 0 & 1 & 0 & 0 & 1 \\
& & & & & & & \\
Total sample size & 93 & 73 & 29 & 51 & 56 & 25 & 328 \\
Number of trapping days & 9 & 10 & 10 & 14 & 16 & 9 & 68 \\
\hline
\end{tabular}

Table 5. The sample size of different carabid species collected by pitfall traps ( $p$ ) and manual collecting ( $m$ ) in three localities. The pitfall sample from Ushuaia is from period IV, and the manual collecting was carried out on January 26 . The total sample sizes are given in the last row.

\begin{tabular}{|c|c|c|c|c|c|c|}
\hline \multirow{2}{*}{ Abropus carnifex } & \multicolumn{2}{|c|}{$\begin{array}{l}\text { IV/4 } \\
\text { p. m. }\end{array}$} & \multicolumn{2}{|c|}{$\begin{array}{l}\text { IV } / 5 \\
\text { p. m. }\end{array}$} & \multicolumn{2}{|c|}{$\begin{array}{l}\text { Ushuai } \\
\text { p. m. }\end{array}$} \\
\hline & 0 & 0 & 15 & 5 & 2 & 1 \\
\hline Antarctonomus & & & & & & \\
\hline complanatus & 0 & 0 & 0 & 0 & 11 & 0 \\
\hline Cascellius ae & 0 & 0 & 0 & c & 0 & 0 \\
\hline Cascellius gravesii & 14 & 11 & 1 & 2 & 7 & 2 \\
\hline Ceroglossus suturalis & 0 & 0 & 10 & 0 & 2 & 1 \\
\hline Migadops latus & 80 & 27 & 0 & 0 & 28 & 25 \\
\hline Oopterus soledadinus & 0 & 0 & 0 & 0 & 1 & 0 \\
\hline Total sample size & 94 & 38 & 26 & 7 & 15 & 29 \\
\hline
\end{tabular}

\section{Discussion}

\subsection{Carabid distribution in southern South America}

This preliminary study on the distribution of carabids in different habitat types in Tierra del Fuego and southern Patagonia indicated that most species are associated with certain habitats. This was to be expected, as carabids are known to show habitat preferences (e.g., Thiele 1977). Since this study is one of the first to describe the habitat associations of carabids in Fuego-Patagonia, it is difficult to discuss the results in relation to other studies; almost no literature about carabid ecology or biogeography is available from southern South America (see e.g. Arnaud et al. 1967).

Although the knowledge about their biogeography and ecology is limited, carabids have been used in studies aiming to delimit biogeographical regions in South America (Kuschel 1960, 1969, O'Brien 1971, Cekalovic 1974, Artigas 1975). These regions are rather broad, and usually no numerical abundance data or information about the habitat distribution of the species within the regions are presented.

Kuschel (1960) and Cekalovic (1974) give some scattered information about the distribution of carabids (mostly genera) in southern Chile, but provide no numerical data. By and large, my observations agree with their data. For instance, Kuschel (1960) states that Cascellius species are characteristic of oceanic heathlands, and Cekalovic (1974) reports that the genera Antarctonomus, Cascellius, Abropus, Aemalodera, Metius and Migadops occur abundantly in the most oceanic parts of Tierra del Fuego and Patagonia. In my records, the oceanic areas are represented by evergreen forests. Thus my observations correlate well with these data, except that Migadops appeared to be a forest generalist and Metius was associated with drier habitat types.

From the humid forest zone, corresponding roughly to habitat types 3-5 in my classification, Cekalovic (1974) reported C. suturalis, and many Metius and Trechisibus species. In my data, Metius species were mostly found in drier habitat types. 
Kuschel (1960) reported that the genera $M i$ gadops, Oopterus, Metius and Abropus are characteristic of the Patagonian steppe, and Cekalovic (1974) claimed that typical inhabitants of the steppe are B. clivinoides, Metius spp., Trechisibus spp., Pycnochila fallaciosa and M. latus. Of these species, I found Barypus, Metius and Oopterus almost exclusively in the steppe region, but Migadops, Trechisibus and especially Abropus were more abundant in the humid forests.

From further north, the lake region of southern Chile (about $40^{\circ} \mathrm{S}, 70^{\circ} \mathrm{W}$ ), Ashworth \& Hoganson (1987) provide information about the distribution of some carabid species along an altitudinal gradient. The forest types are somewhat different there, but the four species found in both the lake region and Tierra del Fuego (A. carnifex, Aemalodera centromaculata, A. testacea and $C$. suturalis) occupied fairly similar habitats (i.e., they favour humid forests).

The trapping period of the continuous sampling in Ushuaia was too short to reveal the annual activity cycle of the species. On the other hand, this was to my knowledge the first attempt to study the question and one of the first large-scale pitfall trappings of carabids conducted in Tierra del Fuego. The sampling period of 68 days is shorter than the thermal growing season, which lasts some 200 days (November till April) in Ushuaia. The records of the temporal occurrence of the species are difficult to assess, partly due to the lack of reference data. The only consistent pattern in the records was the decreasing trend in the abundance of the species from December to February.

The two sampling methods, pitfall trapping and manual collecting, yielded fairly similar catches. Moreover, some differences can be expected, as a larger area, including several microhabitats, had to be covered by manual collecting. The effect of microhabitat variation was evident in site IV/5, where all the $C$. suturalis individuals were caught in some traps located in a moist patch.

\subsection{Transatlantic and bipolar distribution of carabids}

The question of the floral and faunal connections between Tierra del Fuego and corresponding regions in the Southern Hemisphere has been widely discussed (Gressitt 1963). Authors have debated whether the similarities between different, nowadays isolated areas, are the result of movements of the continents or whether dispersal has contributed to the present distribution of the floras and faunas (see e.g. Enderlein 1908, 1909b, Gressitt 1963, 1970, Noonan 1979). Similarities have been found in the carabid faunas, as well (e.g. Pantin 1960, Darlington 1965). Besides being found in Tierra del Fuego, three carabid groups represented in my material (tribe Migadopini, genera Oopterus and Trechisibus) are reported to occur on some subantarctic islands, in New Zealand and Australia (Darlington 1960, 1965, Jeannel 1962, Gressitt 1970, Johns 1974, Lindskog 1987). On the other hand, there are no individual species with a transatlantic distribution in my records. According to the literature, only one such species is known, Kenodactylus audouini (Guérin), which occurs on the Antipodes Islands, Auckland Island, Campbell Island, the Snares Islands, Stewart Island, the Falkland Islands and Patagonia (Johns 1974). Often different species of the same genus occur on different islands, in southern South America and in New Zealand-Australia (Johns 1974, Gressitt 1970). For instance, Oopterus clivinoides Guérin is found on the Antipodes Islands, Auckland Islands and Campbell Island, and $O$. soledadinus (Guérin) is found in southern South America, the Falkland Islands, South Georgia and Kerguelen Island (Johns 1974). Some carabid species are endemic to one or a group of subantarctic islands: Temnostega antarctica Enderlein is found only on Crozet Island (Enderlein 1908, Gressitt 1970).

There are at least four tribes of carabids in southern South America with representatives in the Northern Hemisphere, as well (Enderlein 1905, Gressitt 1970). The tribes Migadopini (genera Migadops and Antarctonomus), Broscini (genus Cascellius) and Trechini (Trechisibus and Nothotrechisibus) were abundant in my records. The fourth one, Bembidion, was very scarce.

To conclude, this study revealed the need of detailed research on the distribution, ecology and taxonomy of carabids in Tierra del Fuego. Further studies are important, for instance, to establish the much debated origin and relationships of the faunas in the different parts of the southern cool 
temperate and subantarctic area (Gressitt 1958, 1963, Knox 1963, Kuschel 1963, Bonniard de Saludo 1968, Johns 1974, Lindskog 1987). Studies are especially urgently required in southern South America, which is entomologically poorly known compared with New Zealand and Australia, and most of the subantarctic islands, such as Campbell Island, the Falkland Islands and Kerguelen (Gressitt \& Weber 1959).

Acknowledgements. My sincere thanks are due to Ilpo Kuokka, Sakari Tuhkanen, Soili Stenroos and Jaakko Hyvönen, the members of the Finnish expedition to Tierra del Fuego and Patagonia in 1986-1987, for making the hard field work in a harsh climate enjoyable, and for comments on the manuscript. I am grateful to Prof. Allan C. Ashworth and to Dr. Nigel Stork for their hospitality and help with the identification of the beetles during my visit to Cambridge (England) and to the British Museum (Natural History). I also want to express my gratitude to Mr. Sergio Roig (Universidad Nacional de La Plata, Argentina) for help in the identification of the carabids. The study was financed by the Academy of Finland and the Emil Aaltonen Foundation. The expedition received financial support from the Oskar Öflund Foundation, as well.

\section{References}

Ashworth, A. C. \& Hoganson J. W. 1987: Coleoptera bioassociations along an elevational gradient in the lake region of southern Chile, and comments on the postglacial development of the fauna. - Ann. Entomol. Soc. Am. 80(6):865-895.

Arnaud, P., Arnaud, F. \& Hureau, J-C. 1967: Bibliographie générale de biologie antarctique et subantarctique (Cétacés exceptés). - Comité national français des recherches antarctiques $18: \mathrm{XVI}+180 \mathrm{pp}$.

Artigas, J. N. 1975: Introducción al estudio por computación de las areas zoogeográficas de Chile continental basado en la distribución de 903 especies de animales terrestres. - Gayana, (Instituto de Biologia, Universidad de Concepcion) (miscelanea \# 4):3-25.

Balazuc, J. 1957: Les Céroglosses. — Rev. Franc. Entomol. 24:213-231.

Beaglehole, J. C. 1962: The Endeavour journals of Joseph Banks, 1768-71, vol. I. - Angus and Robertson, Sydney, 479 pp.

Bonniard de Saludo, P. 1968: Les carabiques du Chili. Université de Toulouse, Faculté des Sciences, thesis, $391 \mathrm{pp}$.

Bruch, C. 1910-1911: Catálogo sistemático de los coleópteros de la república Argentina. - Rev. Mus. la Plata 17 (segunda serie, tomo 4):143-181.

Brundin, L. 1965: On the real nature of transantarctic relationships. - Evolution 19:496-505.
- 1966: Transantarctic relationships and their significance, as evidenced by chironomid midges, with a monograph of the subfamilies Podonominae and Aphroteniinae and the austral Heptagyiae. - Kgl. Svenska Vet.-Akad. Handl. IV, 11(1): 1-472.

Cekalovic, T. 1974: Divisiones biogeográficas de la XII región Chilena (Magallans). - Bol. Soc. Biol. Concepcion 48:297-314.

Champion, G. C. 1918a: The Coleoptera of the Falkland Islands. - Ann. Mag. Nat. Hist. 1:167-186.

- 1918b: Notes on various South American Coleoptera collected by Charles Darwin during the voyage of the "Beagle", with descriptions of new genera and species. — Entomol. Mon. Mag. 54:43-55.

Curtis, J. 1841: Descriptions, \&c. of the insects collected by captain P. P. King, R. N. F. R S. \& L. S. in the survey of the Straits of Magellan. - Trans. Linn. Soc., London 18:181-205.

Darlington, P. J. Jr. 1960: The zoogeography of the southern cold temperate zone. - Proc. R. Soc. London, ser. B 152:659-667.

- 1965: Biogeography of the southern end of the world. - Harvard University Press, 236 pp.

Darwin, C. H. 1979: The voyage of the 'Beagle'. - J. M. Dent \& Sons, London, 496 pp.

Davis, D. R. Nielsen, E. S. 1985: The South American neopseustid genus Apoplania Davis a new species, distribution records and notes on adult behaviour (Lepidoptera: Neopseustina). — Entomol. Scand. 15: 497-509.

Dollenz, O. 1980: Estudios fitosociológicos en el archipiélago Cabo de Hornos, I (Isla Wollaston, Isla Bayly). - An. Inst. Patagonia 11:235-238.

- 1981: Estudios fitosociológicos en el archipiélago Cabo de Hornos, II (Isla Hornos) — An. Inst. Patagonia 12:173-182.

- 1982: Estudios fitosociológicos en el archipiélago Cabo de Hornos, III (Isla Deceit). — An. Inst Patagonia 13:145-151.

Enderlein, G. 1905: Die Laufkäfer der Crozet-Inseln, nach dem Material der Deutschen Südpolar-Expedition. Zool. Anz. 28:716-722.

- 1908: Über die biogeographische Stellung der CrozetInseln. - Zool. Anz. 33:751-753.

- 1909a: Die Insekten des antarktisches Gebiets. - In: von Drygalski, E. (ed.): Deutsche Südpolar-expedition 1901-1903. X. Zoologie II, pp. 361-528.

- 1909b: Die biologische Bedeutung der Antarktis und ihrer Faunengebiete mit besonderer Berücksichtung der Insektenwelt. - In: von Drygalski, E. (ed.): Deutsche Südpolar-expedition 1901-1903. X. Zoologie II, pp. 323-360.

- 1912: Die Insekten des Antarkto-Archiplata-Gebietes (Feuerland, Falklands Inseln, Süd Georgien). - Kgl. Svenska Vet.-Akad. Handl. 48(3):1-170.

Fabricius, J. C. 1775: Systema entomologiae. Flensburgi et Lipsiae, $x x x+832$ pp.

Fairmaire, M. L. 1885: Coléoptères recueillis à la Terre de Feu par la mission de la Romanche et description des espèces nouvelles.-Ann. Soc. Entomol Fr. 6(5):32-62. 
- 1888: Insectes Coléoptères. - In: Mission scientifique du Cap Horn 1882-1883, 6(2). Gauthier-Villiers et. fils, Paris, pp. 3-63.

Gressitt, J. L. 1958: Zoogeography of insects. - Ann. Rev. Entomol. 3:207-230.

- 1961: Problems in the zoogeography of Pacific and antarctic insects. - Pac. Insects Monogr. 2:1-94.

- (ed.) 1963: Pacific basin biogeography, a symposium. - Tenth Pacific Science Congress, Honolulu, 1961. Bishop Museum Press, 563 pp.

- 1970: Subantarctic entomology and biogeography. Pac. Insect Monogr. 23:295-374.

Gressitt, J. L. \& Weber, N. A. 1959: Bibliographic introduction to antarctic-subantarctic entomology. - Pac. Insects 1(4):441-480.

Goodall Prosser, R. N. 1979: Tierra del Fuego. — Ediciones Shanamaiim, Buenos Aires, 329 pp.

Holdgate, M. W. 1961: Biological routes between the southern continents. - New Scientist 239:636-639

Hope, F. W. 1837: Descriptions of some species of Carabidae, collected by Charles Darwin, Esq., in his late voyage. - Trans. Entomol. Soc. London 2:128-131.

Jeannel, R. 1938: Les Migadopides (Coleoptera Adephaga) une lignée subantarctique. - Rev. Fr. Entomol. 5:1-55

- 1961: Sur quelques Trechisibus des environs de Punta Arenas. - Rev. Fr. Entomol. 28:5-7.

- 1962: Les Trechides de la paleantarctide occidentale. — In: Debouttenville, C. D. \& Rapoport, E. (eds.): Biologie de l'Amérique Australe 1:527-655.

Johns, P. M. 1974: Arthropoda of the subantarctic islands of New Zealand (1). Coleoptera: Carabidae. Southern New Zealand, Patagonian, and Falkland Islands insular carabidae. - J. R. Soc. N. Z. 4(3):283-302.

Knox, G. A. 1963: Antarctic relationships in Pacific biogeography. - In: Gressitt, J. L. (ed.): Pacific basin biogeography, a symposium. - Tenth Pacific Science Congress, Honolulu, 1961. Bishop Museum Press, pp. $465-474$.

Kuschel, G. 1960: Terrestrial zoology in southern Chile. Proc. R. Soc. London, ser. B, 152:540-550.

- 1963: Problems concerning an austral region. - In: Gressitt, J. L. (ed.): Pacific basin biogeography, a symposium. - Tenth Pacific Science Congress, Honolulu, 1961. Bishop Museum Press, pp. 443-449.

- 1969: Biogeography and ecology of South American Coleoptera. - In: Fittkau, E. J., Illies, J., Klinge, H., Schwabe, G. H. \& Sioli, H. (eds.): Biogeography and ecology in South America, 2. - Monographiae Biologicae 19:709-722.

Lanfranco, D. L. 1977: Entomofauna asociada a los bosques de Nothofagus pumilio (Poepp. et Endl.) Krasser en la región de Magallanes. 1 parte: Monte Alto, (Río Rubens, Ultima Esperanza). - An. Inst. Patagonia 8:319-348.

- 1981: Estudios entomofaunisticos en el archipiélago del Cabo de Hornos. 2. Prospección preliminar de suelo-superficie en Surgidero Romanche (Isla Bayly). - An. Inst. Patagonia 12:229-238.

Lindskog, P. 1987: Sydgeorgiens insekter, biogeografisk utblick. - Fauna och Flora 82:38-42.
Madsen, H. B., Schmidt Nielsen, E. \& Ödum, S. 1980: The Danish Scientific Expedition to Patagonia and Tierra del Fuego 1978-1979. — Geogr. Tidsskr. 80:1-28.

Mateu, J. \& Négre, J. 1972: Révision de genre Trechisibus Motsch, et genres voisins. - Nouv. Rev. Entomol. 2:53-72.

Négre, J. 1972: The zoological results of Gy. Topal's collectings in south Argentine 24. Coléoptères: Carabidae. - Folia Entomol. Hung. 26 (suppl):289-310.

Noonan, G. R. 1979: The science of biogeography with relation to Carabids. - In: Erwin, T. L., Ball, G. E. \& Whitehead, D. R. (eds.): Carabid beetles. Their evolution, natural history and classification. - Junk, the Hague, pp. 295-317.

O'Brien, C. W. 1971: The biogeography of Chile through entomofaunal regions. - Entomol. News 82:197-207.

Ohlin, A. 1896: Kort berättelse öfver de zoologiska arbeten, som utförts under den svenska Eldslandsexpeditionen 1895-1896. — Öfv. Kgl. Vet.-Akad. Förh. 6:483-501.

Pantin, C. F. A. 1960: A discussion on the biology of the southern cold temperate zone. - Proc. R. Soc. London, ser. B, 152:429-682.

Peña, L. E. 1966: A preliminary attempt to divide Chile into entomofaunal regions, based on the Tenebrionidae (Coleoptera). - Postilla 97:1-17.

Pisano, E. 1977: Fitogeográfia de Fuego-Patagonia Chilena, I. Comunidades vegetales entre las latitudes 52 y $56 \mathrm{~S}$. - An. Inst. Patagonia 8:121-250.

- 1980: Distribución y características de la vegetación del archipiélago del Cabo de Hornos. - An. Inst. Patagonia 11: 191-224.

- 1981: Bosquejo fitogeográfico de Fuego-Patagonia. An. Inst. Patagonia 12:159-171.

- 1982: Comunidades vegetales vasculares de la Isla Hornos. - An. Inst. Patagonia 13:125-143.

Reichart, H. 1977: A synopsis of the genera of Neotropical Carabidae (Insecta: Coleoptera). — Quaest. Entomol. 13: 346-493.

Roivainen, H. 1954: Studien über die Moore Feuerlands. Ann. Bot. Soc. 'Vanamo' 28(2):1-205.

Ruiz Pereira, F. 1936: Los Ceroglossus de Chile (Col. Carabidae). - Rev. Chil. Hist. Nat. 40:381-425.

Schwaar, J. 1981: Amphi-arktische Pflanzengesellschaften in Feuerland. - Phytocoenologia 9(4):547.572.

Schweiger, H. 1958: Über einige von der Skottsbergexpedition im Antarktoarchiplata-Gebiet aufgesammelte Koleopteren. - Ark. Zool. ser. 2, 12(1):1-43.

Simpson, G. G. 1940: Antarctica as a faunal migration route. - Proc. Sixth Pacific Sci. Congr. 2:755-760.

Smith, K. G. V. (ed.). 1987: Darwin's Insects, Charles Darwin's Entomological Notes. - Bull. Br. Mus. (Nat. Hist.) Hist. ser. 14(1):1-143.

Straneo, S. L. 1951: Sur la tribu des Metiini (Antarctiini Auct.) (Coleoptera, Pterostichidae). - Rev. Fr. Entomol. 18:56-88.

- 1969: Sui Carabidi del Chile, raccolti dal Dr. Holdgate della Royal Society Expedition (1958-1959) e dal prof. Kuschel. - Ann. Soc. Entomol. Fr., NS 5(4):951-974. 
- 1979: Notes about classification of the South American Pterostichini with a key for determination of subtribes, genera and subgenera (Coleoptera: Carabidae). Quaest. Entomol. 15: 345-356.

Thiele, H-U. 1977: Carabid beetles in their environments. - Springer Verlag, Berlin, 369 pp.

Tuhkanen, S. 1987: The phytogeographical position of the Faeroe Islands and their ecoclimatic correspondences on the other continents: Problems associated with highly oceanic areas. - Ann. Bot. Fennici 24:111-135.
Uéno, S.-I. 1971: The affinities of three Trechid beetles from South America. - Bull. Nat. Sci. Mus., Tokyo, 14:553-569.

Waterhouse, G. R. 1841: Carabideous insects collected by Mr. Darwin during the voyage of Her Majesty's ship Beagle. - Ann. Mag. Nat. Hist., 6:254-257.

- 1842: Carabideous insects collected by Charles Darwin, Esq., during the voyage of Her Majesty's ship Beagle. - Ann. Mag. Nat. Hist., 9:134-139.

Appendix 1. The classification of the sampling localities into the five habitat types (see sect. 3.2), $-=$ locality excluded from the classification, and the number of specimens $(n)$ of each carabid species (see codes below) in the localities. Localities where no carabids were found are not listed. An s after the locality code indicates sample taken by sieving, a $\mathrm{p}$ by pitfall trapping.

Species codes: 1 = Abropus carnifex (Fabricius), $2=$ Aemalodera centromaculata Solier, $3=$ Aemalodera testacea (Jeannel), 4 = Antarctonomus complanatus (Blanchard), $5=$ Barypus clivinoides (Curtis), $6=$ Bembidini sp., $7=$ Bembidiomorphum convexum Champion, $8=$ Cascellius aeneoniger Waterhouse, $9=$ Cascellius gravesii Curtis, 10 = Cascellius hyadesi Fairmaire, $11=$ Ceroglossus suturalis (Fabricius), $12=$ Metius blandus (Dejean), $13=$ Metius bradytoides (Fairmaire), $14=$ Metius sp. 2., $15=$ Metius sp. 3., $16=$ Metius sp. 4., $17=$ Metius sp. 5., 18 = Metius sp. 7., 19 = Migadops latus (Guérin-Méneville), 20 = Nothotrechisibus hornensis (Fairmaire), 21 = Oopterus soledadinus (Guérin), 22 = Plagiotelum irinum Solier, 23 = Pycnochila fallaciosa Chevrolat, $24=$ Trechisibus sp. 1., $25=$ Trechisibus sp. 2., $26=$ Trechisibus sp. $3 ., 27=$ Trirammatus sp., $28=$ Harpalini (Anisodactylini) sp.

The additional study localities are given after the transect localities with the following abbreviations: $A=$ dry grassland, grazed, near Est. Haberton (Argentina, T. d. F); B = Nothofagus antarctica scrub, duck-grazed, Juncus-Gunnera short-herb coastal meadow, Bahia Valentin (Arg. T. d. F); C = sand-gravel stony road verge, near locality IV/05 (Arg., T. d. F); D = Hierochloe-Phleum tall grassland on a clearing, near locality III/11 (Chile, T. d. F); $E=$ herb-poor N. pumilioforest (Arg., T. d. F, L. Fagnano); F = Astelia blanket bog on Isla Navarino (Chile, T. d. F); $G$ = stony road verge in Ushuaia (Arg., T. d. F); $H$ = dry, short grassland, grazed at Puesto Donata, $P$. Mitre (Arg., T. d. F); I = dry, short grassland grazed with Chiliotrichum diffusum at Boqueron near locality II/04 (Chile, T. d. F); J = N. pumilio-N. betuloides forest on Isla Navarino (Chile, T. d. F); K = Caltha-Gunnera heavily grazed short grass meadow (Chile, T. d. F); $L=N$. pumilio-dominated forest (Arg., T. d. F); $M=$ steppe, San Sebastian at locality III/1, pitfalls (Arg., T. d. F); N = steppe woodland, Kaiken, pitfalls (Arg., T. d. F); $\mathrm{O}=$ AsteliaPilgerodendron blanket bog on Isla Clarence, pitfalls (Chile, T. d. F). P = manual collecting in Ushuaia pitfall grid (see sect. 3.3); $Q$ = pitfall trapping near Ushuaia (see sect. 3.3).

\begin{tabular}{|c|c|c|c|c|c|c|c|}
\hline Locality & Type & Total & Species : $n$ & Locality & Type & Total & Species : $n$ \\
\hline \multirow[t]{2}{*}{$1 / 01$} & \multirow[t]{2}{*}{4} & \multirow[t]{2}{*}{23} & \multirow{2}{*}{$\begin{array}{l}1: 3,9: 7,12: 9,15: 1,17: 1 \\
26: 2\end{array}$} & III/07 & 4 & 20 & $1: 13,4: 1,9: 2,11: 3,19: 1$ \\
\hline & & & & III/08 & 3 & 39 & $9: 13,19: 26$ \\
\hline 1/02 & 4 & 13 & $1: 2,9: 3,11: 1,2: 1,19: 6$ & III/09 & 3 & 23 & $9: 9,19: 14$ \\
\hline 1/03 & 5 & 6 & $1: 3,11: 3$ & $\mathrm{III} / 10$ & 3 & 24 & $19: 11,24: 12,25: 1$ \\
\hline $1 / 04$ & - & 1 & $2: 1$ & $\| I \mid / 11$ & 5 & 8 & $1: 1,9: 1,11: 5,19: 1$ \\
\hline 1/07 & - & 1 & $8: 1$ & $\| I \mid / 12$ & 4 & 41 & $1: 24,9: 13,19: 4$ \\
\hline 1/08 & - & 1 & $10: 1$ & IV/01 & 1 & 4 & $12: 1,13: 1,14: 2$ \\
\hline $\mid / 11$ & - & 1 & $10: 1$ & IV/02 & 4 & 21 & $9: 21$ \\
\hline II/01\&02 & 1 & 37 & $13: 36,18: 1$ & IV/03 & 5 & 40 & $9: 6,13: 1,19: 32,25: 1$ \\
\hline II/03 & 1 & 17 & $12: 2,13: 9,19: 6$ & IV/04 & 2 & 38 & $9: 11,19: 27$ \\
\hline II/04 & 1 & 8 & $12: 7,15: 1$ & IV/04p & - & 94 & $9: 14,19: 80$ \\
\hline $11 / 04 s$ & - & 2 & $12: 2$ & IV/05 & 4 & 7 & $1: 5,9: 2$ \\
\hline II/05 & 1 & 15 & $12: 12,15: 2,18: 1$ & IV/05p & - & 26 & $1: 15,9: 1,11: 10$ \\
\hline III/03 & 1 & 5 & $12: 1,14: 1,16: 2,23: 1$ & IV/06 & 2 & 36 & $9: 6,19: 30$ \\
\hline III/04 & 1 & 3 & $14: 1,15: 1,16: 1$ & IV/07 & 2 & 62 & $9: 8,19: 11,25: 43$ \\
\hline III/05 & 2 & 18 & $9: 6,11: 1,19: 11$ & IV/07s & - & 9 & $25: 9$ \\
\hline III/06 & 2 & 13 & $9: 2,12: 1,19: 10$ & IV/09 & - & 3 & $12: 2,19: 1$ \\
\hline
\end{tabular}




\begin{tabular}{|c|c|c|c|c|c|c|c|}
\hline Locality & Type & Total & Species : $n$ & Locality & Type & Total & Species : $n$ \\
\hline IV/10 & 2 & 27 & $9: 9,3: 1,19: 16,25: 1$ & VII/01 & 5 & 48 & $1: 31,4: 8,9: 2,19: 7$ \\
\hline $\mathrm{IV} / 10 \mathrm{~s}$ & - & 2 & $25: 2$ & VII/02 & 4 & 9 & $1: 4,4: 3,9: 2$ \\
\hline $\mathrm{IV} / 11$ & 2 & 8 & $19: 8$ & VII/03 & 5 & 10 & $4: 4,9: 6$ \\
\hline IV/12 & 3 & 13 & $2: 1,9: 1,19: 10,22: 1$ & VII/04 & 4 & 7 & $1: 1,4: 2,9: 3,19: 1$ \\
\hline $\mathrm{IV} / 14$ & 2 & 2 & $9: 1,12: 1$ & VII/05 & 5 & 1 & $10: 1$ \\
\hline IV/15 & 4 & 23 & $1: 8,9: 3,2: 1,19: 5,8: 6$ & VII/06 & 5 & 31 & $1: 15,4: 9,9: 5,10: 1,11: 1$ \\
\hline $\mathrm{IV} / 16$ & 3 & 101 & $19: 39,20: 62$ & VII/07 & 5 & 10 & $1: 3,4: 1,9: 4,10: 2$ \\
\hline IV/17 & 3 & 35 & $20: 35$ & VII/08 & 4 & 37 & $1: 28,4: 6,9: 1,11: 1,19: 1$ \\
\hline $\mathrm{IV} / 17 \mathrm{~s}$ & - & 2 & $20: 2$ & VII/09 & 4 & 5 & $1: 1,4: 4$ \\
\hline $\mathrm{IV} / 18$ & 5 & 17 & $9: 1,19: 16$ & A & - & 11 & $12: 10,25: 1$ \\
\hline $\mathrm{IV} / 19$ & 5 & 14 & $9: 11,19: 3$ & B & - & 11 & $21: 10,13: 1$ \\
\hline IV/20 & 3 & 16 & $9: 12,19: 2,20: 2$ & C & - & 23 & $26: 23$ \\
\hline IV/21 & 3 & 42 & $20: 42$ & D & - & 19 & $9: 1,12: 1,13: 7,19: 1,26: 7$ \\
\hline IV/22 & 3 & 20 & $9: 1,19: 19$ & & & & $27: 1,28: 1$ \\
\hline IV/23 & 4 & 4 & $9: 4$ & E & - & 6 & $25: 6$ \\
\hline IV/24 & 4 & 13 & $1: 1,9: 5,19: 7$ & $\mathrm{~F}$ & - & 5 & $7: 5$ \\
\hline IV/25 & 3 & 34 & $1: 16,9: 4,11: 3,19: 11$ & G & - & 7 & $21: 6,12: 1$ \\
\hline IV/27 & 4 & 11 & $1: 2,8: 1,9: 1,19: 7$ & $\mathrm{H}$ & - & 16 & $17: 1,25: 15$ \\
\hline V/01 & 5 & 43 & $1: 37,8: 2,11: 1,2: 1,19: 2$ & 1 & - & 9 & $5: 4,12: 1,14: 1,15: 3$ \\
\hline V/02 & 4 & 31 & $1: 13,9: 4,11: 2,19: 12$ & $\mathrm{~J}$ & - & 6 & $13: 1,15: 4,17: 1$ \\
\hline $\mathrm{V} / 03$ & 3 & 19 & $9: 4,19: 15$ & $\mathrm{~K}$ & - & 41 & $4: 1,5: 5,6: 3,12: 1,13: 2$ \\
\hline V/04 & - & 1 & $12: 1$ & & & & $19: 4,25: 25$ \\
\hline V/05 & 4 & 2 & $1: 1,19: 1$ & $\mathrm{~L}$ & - & 4 & $2: 1,11: 3$ \\
\hline V/06 & 3 & 24 & $1: 9,8: 1,9: 2,19: 12$ & M & - & 6 & $17: 6$ \\
\hline $\mathrm{V} / 07$ & 5 & 10 & $1: 5,9: 3,19: 2$ & $\mathrm{~N}$ & - & 22 & $17: 9,12: 2,25: 11$ \\
\hline V/08 & 3 & 15 & $1: 1,9: 8,12: 3,19: 3$ & $\mathrm{O}$ & - & 1 & $11: 1$ \\
\hline $\mathrm{VI} / 01$ & 3 & 8 & $12: 4,19: 4$ & $P$ & - & 29 & $1: 1,9: 2,11: 1,19: 25$ \\
\hline $\mathrm{VI} / 02$ & 3 & 34 & $4: 6,9: 1,11: 5,12: 1,19: 21$ & $\mathrm{Q}$ & - & 328 & $1: 23,4: 91,9: 55,11: 23$ \\
\hline $\mathrm{VI} / 03$ & 4 & 73 & $1: 47,9: 5,19: 20,22: 1$ & & & & $19: 135,21: 1$ \\
\hline VI/04 & 5 & 35 & $1: 30,9: 2,11: 1,19: 2$ & & & & \\
\hline VI/05 & 5 & 103 & $1: 69,4: 8,9: 4,11: 2,19: 20$ & Total & & 2143 & \\
\hline
\end{tabular}

